Proterozoic Transpressive Deformation in the Northern Marginal Zone, Limpopo Belt, Zimbabwe

Author(s): B. S. Kamber, T. G. Blenkinsop, I. M. Villa and P. S. Dahl

Source: The Journal of Geology, Vol. 103, No. 5 (Sep., 1995), pp. 493-508

Published by: The University of Chicago Press

Stable URL: http://www.jstor.org/stable/30070773

Accessed: 14-12-2016 13:03 UTC

JSTOR is a not-for-profit service that helps scholars, researchers, and students discover, use, and build upon a wide range of content in a trusted digital archive. We use information technology and tools to increase productivity and facilitate new forms of scholarship. For more information about JSTOR, please contact support@jstor.org.

Your use of the JSTOR archive indicates your acceptance of the Terms \& Conditions of Use, available at http://about.jstor.org/terms

The University of Chicago Press is collaborating with JSTOR to digitize, preserve and extend access to The Journal of Geology 


\title{
Proterozoic Transpressive Deformation in the Northern Marginal Zone, Limpopo Belt, Zimbabwe ${ }^{1}$
}

\author{
B. S. Kamber, T. G. Blenkinsop ${ }^{3}$, I. M. Villa, and P. S. Dahl ${ }^{4}$ \\ Universität Bern, Mineralogisch-petrographisches Institut, Gruppe Isotopengeologie, \\ Erlachstr. 9a, 3012 Bern, Switzerland
}

\begin{abstract}
A B S TRACT
A major tectono-metamorphic event affected the southern half of the Northern Marginal Zone of the Limpopo Belt at $2.0 \mathrm{Ga}$. Structural analysis along a $43 \mathrm{~km}$-long profile perpendicular to strike shows extension inclined toward the northeast, extension parallel to axes of folds that uplift the southeast of the section (i.e., the Central Zone of the Limpopo Belt), and dextral shear. These deformation patterns developed coevally. The lineations form distinct, tightly clustered groups that occur together in the profile: there is no evidence for superimposed deformation or deformed lineations, nor are lineations observed cross-cutting each other. This single episode of deformation can therefore be called transpression. Petrographic and thermobarometric evidence support this kinematic picture, in that decreases of both pressure $(2.5 \mathrm{~kb})$ and temperature $\left(150^{\circ} \mathrm{C}\right)$ are documented from southeast to northwest across strike. ${ }^{39} \mathrm{Ar}{ }^{40} \mathrm{Ar}$ step-heating of metamorphic hornblende from amphibolites has yielded ages of $2.00 \mathrm{Ga}$ in the northwest; based on a redefinition of closure temperatures in amphiboles, we propose that this is the age of the peak conditions $16.5 \mathrm{~kb}$, $600-650^{\circ} \mathrm{C}$ ) of the transpressional episode. This age is in agreement with existing $\mathrm{Pb} / \mathrm{Pb}$ and $\mathrm{Sm} / \mathrm{Nd}$ garnet ages for the dextral shear in the southeast. In contrast, biotite in the northwest yields an $\mathrm{Rb} / \mathrm{Sr}$ age of $1.86 \mathrm{Ga}$ and coupled with existing garnet and sphene data, this suggests a post-transpressional cooling rate of $1.0 \pm 0.5 \mathrm{~K} / \mathrm{m}$.y. We obtained five near-plateau ages between 2.00 and $1.94 \mathrm{Ga}$ in chemically diverse hornblendes from adjacent amphibolites. Because the hornblendes show negligible evidence for mineralogical and microstructural recrystallization, this age spread probably reflects chemically dependent diffusivity differences upon uniform slow cooling; it can be quantitatively modeled using the concept of "ionic porosity," $Z$. In our samples, $Z$ ranges from $36.7 \%$ to $37.8 \%$; the extreme values correspond to a $41 \pm 9 \mathrm{~K}$ difference in the model closure temperature. This translates into a model cooling rate of $0.7_{-0.3}^{+0.9} \mathrm{~K} / \mathrm{m}$.y. Within error this agrees with the independent cooling rate from garnet, sphene, and biotite. Biotites in the southeastern block yield an $\mathrm{Rb} / \mathrm{Sr}$ age of $1.97 \mathrm{Ga}$, suggesting faster cooling than in the northeast. Contrasting cooling histories north and south of the studied Transition Zone following a 2.00 Ga tectonometamorphism entirely independent of and superimposed on the late Archean event negates the hypothesis of slow cooling after a supposed 2.65 Ga Tibetan-style orogeny. Vital parts of the evidence for such late Archean continental collision models for the Limpopo Belt can now be shown to be early Proterozoic in age.
\end{abstract}

\section{Introduction}

The Limpopo Belt in southern Africa has long been regarded as a typical example of a major Archean deformation zone. A variety of large-scale tectonic models have been proposed for its evolution. They can be broadly classified into those advocating

\footnotetext{
${ }^{1}$ Manuscript received August 16, 1994; accepted April 11, 1995.

${ }^{2}$ Present address: Department of Earth Sciences, University of Cambridge, Downing Street, Cambridge, CB2 3EQ, UK.

${ }^{3}$ Department of Geology, University of Zimbabwe, P.O. Box MP 167, Harare, Zimbabwe.

${ }^{4}$ Department of Geol. Sci., Kent State University, Kent, OH 44242, USA.
}

some form of plate tectonic setting and those suggesting that a different style of tectonics operated during Archean deformation. Plate tectonic models have been popularized recently in a number of publications (De Wit et al. 1992; Windley 1993; Rollinson 1993). The uniformitarian thought behind the plate tectonic models was stressed particularly by Windley (1993) and contrasts with the Marcy model of Kramers (1988) and Ridley and Kramers (1990) as applied to the Limpopo Belt by Ridley (1992).

The Limpopo Belt has been divided into three major tectonic units; the Northern and Southern

[The Journal of Geology, 1995, volume 103, p. 493-508] ๔ 1995 by The University of Chicago. All rights reserved. 0022-1376/95/10305-002\$1.00 
Marginal Zones, and the Central Zone (Cox et al. 1965). This distinction was originally recognized on the basis of lineament patterns observed from aerial photographs, and while the position of the boundaries between the zones has varied among later publications, a tripartite division is still accepted by all workers. The division is now made on the basis of rock types, metamorphic petrology, and isotopic characteristics as well as structures that are mainly responsible for the lineament patterns observed by Cox et al. (1965).

This study focuses on the relationship between the Northern Marginal Zone and the Central Zone. The boundary between these two units is a structure of crustal scale (Coward and Fairhead 1980) and must be regarded as a key feature of the entire Limpopo Belt. Its importance is highlighted in all large-scale models for the Limpopo Belt referred to above but has been subject to a variety of interpretations. Coward and coworkers regarded the boundary as a thrust on which the Kaapvaal craton was emplaced over the Zimbabwe craton, and along which later strike-slip displacement occurred (Coward 1976; Coward and Fairhead 1980). Archean juxtaposition of the Central Zone with the Northern Marginal Zone was suggested by Barton and Key (1981), Watkeys (1984), and Barton et al. (1990). The importance of strike-slip deformation along the boundary between the Central Zone and the Northern Marginal Zone was emphasized in the model of McCourt and Vearncombe (1987, 1992) who regarded the whole orogeny as a product of the emplacement of the Central Zone to the southwest relative to the marginal zones during the late Archean. Van Breemen and Hawkesworth (1980) found evidence for garnet growth under granulite facies conditions at $1.98 \mathrm{Ga}$ in the boundary between the Central Zone and the Northern Marginal Zone, but such Proterozoic deformation was regarded as late reactivation of a primary late Archean feature by McCourt and Vearncombe (1992). Roering et al. (1992) pointed out difficulties with the McCourt and Vearncombe model, although they also regarded the Central Zone as allochthonous. They considered the contact between the Central Zone and the Northern Marginal Zone to be a thrust. Rollinson (1993) emphasized the allochthonous nature of the Central Zone and suggested that it may have been accreted as an exotic terrane. The models of De Wit et al. (1992) and Windley (1993) suggested that the contact between the Central Zone and the Northern Marginal Zone is a suture between two colliding continents. Himalayan style tectonics are invoked by Treloar et al. (1992) as an analogy for the Limpopo Belt: in this view, the Central Zone is regarded as extruded along two strike-slip shear zones during the late Archean. However, the most recent work has shown clearly that the contact between the Central Zone and the Northern Marginal Zone experienced a major phase of granulite facies metamorphism at $\approx 2.0 \mathrm{Ga}$ (Kamber et al. 1995). In summary, there are major disagreements over the timing and significance of the contact between the Central Zone and the Northern Marginal Zone.

Several studies have focused on the nature of the boundary between the Northern Marginal Zone and the Central Zone. This was first described in detail by James (1975) in the area around Triangle, where he recognized a major dextral shear zone approximately $50 \mathrm{~km}$ long and $25 \mathrm{~km}$ wide and an approximately $5 \mathrm{~km}$ wide transition to the northwest into the Northern Marginal Zone. Rollinson and Blenkinsop (1995) have shown that the dextral shear zone, the Triangle shear zone, is continuous along the southern edge of the Northern Marginal Zone from the Karoo cover near Bubye river, southwest of Triangle (figure 1), to the overlying Umkondo rocks to the northeast of Triangle. These authors also identified a Transition Zone extending along the same strike length as the Triangle shear zone lying to the north of it /figure 1); thus these two structures together-the Triangle shear zone and the Transition Zone-make up the boundary between the Central and the Northern Marginal Zone of the Limpopo Belt. Strike-slip movement along the Triangle shear zone happened under granulite facies conditions (Kamber et al. 1995; Rollinson and Blenkinsop 1995). It was dated to $\approx 2.0 \mathrm{Ga}$ by van Breemen and Hawkesworth (1980), an age which was subsequently reproduced by Kamber et al. (1995).

In this study we investigate the tectonic style of the Central Zone-Northern Marginal Zone boundary; thus both in the Transition Zone and the Triangle Shear Zone. In addition, we present thermobarometric results and time constraints on the tectono-metamorphism recorded in the Transition Zone. Combined with existing petrologic and age data from the Triangle shear zone (i.e., van Breemen and Hawkesworth 1980; Kamber et al. 1995), we draw implications for possible tectonic models for the entire Limpopo Belt. Our results have been obtained along a detailed $43 \mathrm{~km}$ profile down the Mwenezi river in the south of Zimbabwe, where a well-exposed and complete traverse can be made from the Northern Marginal Zone through the Triangle shear zone (figure 1). The strikingly different cooling histories north and south of the Northern Marinal Zone-Central Zone 


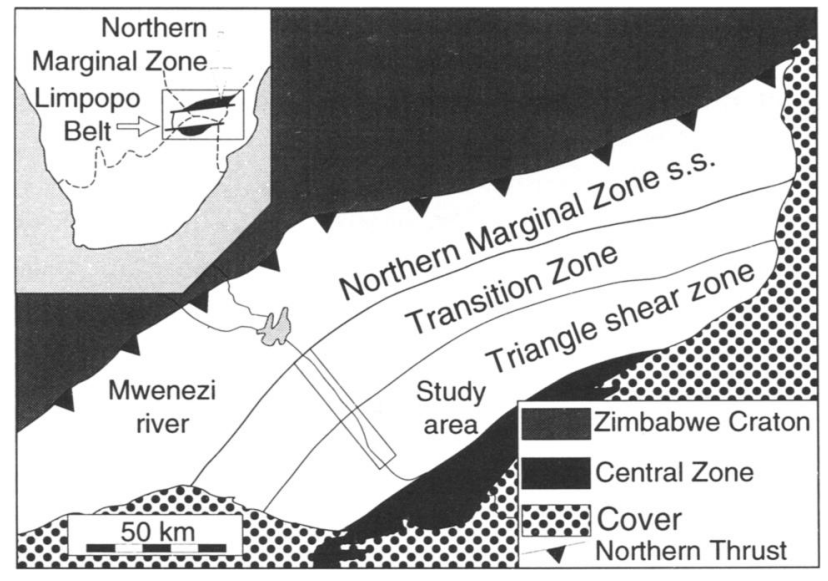

Figure 1. Tectonic overview of the Northern Marginal Zone shows the tripartite division into the Triangle shear zone, the Transition zone, and the Northern Marginal Zone s.s., which has only been weakly affected by the Proterozoic tectono-metamorphism. Box along the Mwenezi river indicates the location of the studied profile.

boundary, as well as the peculiar tectonic style of the boundary itself, are discussed.

\section{Petrography}

The entire Northern Marginal Zone is predominantly composed of late Archean orthogneisses in which metabasic and metasedimentary units are found as septa. Except for the youngest porphyritic granites $(\approx 2.6 \mathrm{Ga}$, Mkweli et al. 1995) and the Great Dyke system $(2461 \pm 16 \mathrm{Ma}$, Hamilton 1977) all rocks show a variable degree of $2.60 \mathrm{Ga}$ granulite facies structural and metamorphic overprint. A post-Great Dyke lower-grade tectonometamorphism has been suggested by a number of authors (e.g., Morgan 1984 and references therein). Our lithological classification along the studied profile into seven different rock types is based on the type of protolith and the kind of metamorphic and structural overprint recorded. The distribution of these lithologies is shown on figures 2 and 4. It should be noted that the classification into lithologies does not coincide with the division of the profile into seven structural sections (figure 4).

1) Occurring only at the northern end of the Mwenezi profile in structural section 1 are charnoenderbites and charnoenderbitic gneissees. They are the dominant rock types responsible for the characteristic whale-back landscape to the north of the study area. They consist of quartz, K-feldspar, plagioclase, biotite, orthopyroxene and magnetite ( \pm clinopyroxene \pm hornblende) with a medium

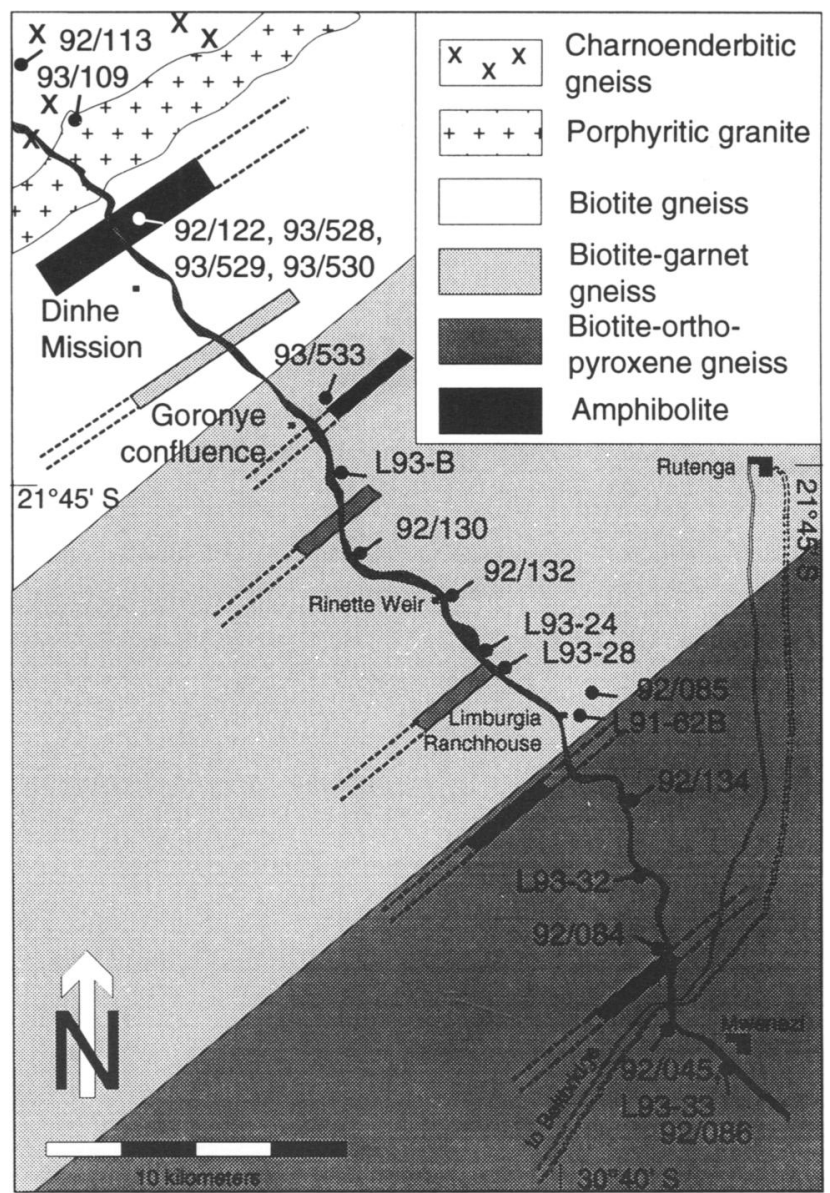

Figure 2. Simplified geologic map with sample localities covering the study area.

grain size. The K-feldspar is commonly perthitic. They are petrographically and geochemically recognizable as orthogranulites with compositions ranging from quartz-diorite to trondjhemite, tonalite and granodiorite (Rollinson and Blenkinsop 1995), are the same group of rocks referred to as charnockite-enderbite gneisses by Ridley (1992), and form part of the "Plutonic Assemblage" of Rollinson and Blenkinsop (1995). Using a combined geochemical, isotope-geochemical, and geochronological approach, Berger et al. (1995) have recently been able to verify the presence of orthogranulites and have dated their intrusion at 2.71 to $2.62 \mathrm{Ga}$. The original magmatic textures are variably overprinted and range from granoblastic polygonal to well-foliated and banded gneissic.

2) A body of porphyritic biotite-granite intrusive into the charnoenderbitic gneisses near the northern end of the profile in structural section 1 is distinctive for its K-feldspar porphyroclasts approximately $3 \mathrm{~cm}$ long, which make up $30 \%$ to $40 \%$ of the rock. These define a weak to strong L-S fabric. 
The granite consists of K-feldspar, quartz, plagioclase, brown biotite, and magnetite. The appearance and intrusive relationship are similar to the $\approx 2.6 \mathrm{Ga}$ porphyritic granites outcropping farther north in the Northern Marginal Zone s.s. described as the Razi suite by Robertson (1973), but the mineralogy of the former granite differs insofar as hornblende is absent.

3) The majority of rocks in the northwestern half of the profile are grey-pink biotite gneisses. Their mineralogy is similar to that of the porphyritic granite (2) with medium grain sizes and weak to moderate foliation defined mostly by biotite flakes, and compositional gneissic banding. Their fabric-forming mineralogy is thus typical of lower to mid-amphibolite-facies, contrasting the granulite-facies mineralogy in the Northern Marginal Zone s.s. (Berger et al. 1995). Retrograde minerals include fine-grained muscovite and green chlorite replacing biotite.

4) Grey biotite-orthopyroxene gneisses dominate the southwestern half of the profile. Their mineralogy is similar to the biotite gneisses with the addition of orthopyroxene $1 \pm$ green hornblende). Garnet and clinopyroxene occur in the more aluminous plagioclase-rich varieties and become widespread in the southernmost $15 \mathrm{~km}$ of the section.

5) Clinopyroxene-free amphibolites consist of hornblende, plagioclase, quartz, and sphene, which is always contained in hornblende ( \pm garnet, \pm orthopyroxene). Hornblende with a grain size of 0.5-1 mm usually defines a good L-S fabric, and there are also coarser-grained varieties with hornblende crystals several millimeters long. Again, the fact that hornblende defines the lineation contrasts the situation in the Northern Marginal Zone s.s., where deformation was coeval with hornblendeout (to pyroxene and plagioclase) reactions. A body of this amphibolite more than $1.5 \mathrm{~km}$ wide outcrops north of Dinhe mission, and sheets several meters wide occur elsewhere along the profile (figures 2 and 4).

6) Two-pyroxene amphibolites are found exclusively in the southeastern part of the section. They consist of brown hornblende, orthopyroxene, clinopyroxene, plagioclase, and quartz ( \pm garnet).

7) Paragneisses are extremely rare as elsewhere in the Northern Marginal Zone. In fact the only certain meta-sedimentary gneiss is a meta-ironformation. It consists of magnetite, quartz, orthopyroxene, clinopyroxene, garnet, and traces of hornblende and rutile. Pyroxene crystals reach a length of $5 \mathrm{~mm}$, and a strong foliation is defined by the inequant shape of most grains.
The rocks in the Transition Zone and the Triangle shear zone, although representing similar protoliths, show marked differences to their counterparts in the Northern Marginal Zone s.s. (figure 1). They differ in their mineral assemblages, the nature of their tectonic overprint, and the metamorphic temperatures at which they were deformed. The late Archean tectonometamorphism happened under low-pressure granulite facies, which explains why garnet is absent from mafic lithologies and confined to migmatized felsic gneisses in Northern Marginal Zone s.s. as well as the complete absence of rutile in metapelitic granulites. This strongly contrasts with the mineralogy in the studied profile, where these minerals are frequently found. Most important however is the marked mineralogical change in chemically similar felsic and mafic rocks preserved along the profile itself. It can qualitatively be ascribed to an increase of metamorphic PT conditions from amphibolite facies to granulitic conditions in a northwest to southeast direction. This increase is exactly opposite to the one expected for a single late Archean tectonometamorphic event, because in that case we would expect the metamorphic conditions to decrease from the Northern Marginal Zone s.s. (low-pressure granulite) to the Transition Zone (amphibolite facies) into the Triangle shear zone. Because the Triangle shear zone records equilibration at very high temperatures and moderate pressures, dated at $2.0 \mathrm{Ga}$ (van Breemen and Hawkesworth 1980 and Kamber et al. 1995), it might also be that the amphibolite facies recrystallization in the adjacent Transition Zone was coeval. In this case, the mineralogical changes along the profile would represent a decrease in metamorphic PT conditions from southeast to northwest during the $2.0 \mathrm{Ga}$ overprint, affecting the Northern Marginal Zone s.s. only inasmuch as the $\mathrm{Rb} / \mathrm{Sr}$ system in biotite became reset (e.g. van Breemen and Dodson 1972).

\section{Metamorphic PT Conditions}

In order to quantify the petrographical observation of a change in metamorphic conditions we selected eight texturally well-equilibrated rocks mainly from the northern half of the profile, complementary to the set of Kamber et al. (1995) who chiefly sampled the southern half of the section (figure 2), to calculate apparent PT conditions of equlibration. We have used the same approach and thermodynamic database as described by Kamber et al. (1995) to ensure internal consistency and to allow for direct comparison with their data. 
The narrow range of lithologies /especially the absence of meta-sedimentary lithologies) limits potential geothermo- and barometers. Estimates of equilibrium temperatures were obtained from the following five reactions (symbols as in Kretz 1983):

$$
\begin{gathered}
\text { phl }+ \text { alm }=\text { ann }+ \text { py } \\
\text { alm }+3 \text { di }=\text { py }+3 \text { hd } \\
\text { tsc }+ \text { alm }=\text { Fe-tsc }+ \text { py } \\
3 \text { en }+2 \text { alm }=3 \text { fsl }+2 \text { py } \\
2 \text { di }+ \text { fsl }=2 \text { hd }+ \text { en }
\end{gathered}
$$

Equilibrium pressure estimates are based on the following four barometric reactions:

$$
\begin{array}{cc}
3 \mathrm{di}+3 \mathrm{an}=2 \mathrm{gr}+\mathrm{py}+3 \mathrm{qtz} & {[6]} \\
3 \mathrm{en}+2 \mathrm{an}=\mathrm{gr}+2 \mathrm{py}+3 \mathrm{qtz} \\
12 \mathrm{an}+3 \mathrm{tr}=3 \mathrm{tsc}+12 \mathrm{qtz}+2 \mathrm{py}+4 \mathrm{gr} & {[8]} \\
2 \mathrm{an}+\mathrm{tr}=2 \mathrm{di}+2 \mathrm{qtz}+\mathrm{tsc}
\end{array}
$$

Analytical Technique. Mineral phases were analyzed with a Cameca $\mathrm{SX} 50^{\circledR}$ electron microprobe operating with $15 \mathrm{kV}$ acceleration and $20 \mathrm{nA}$ beam current. Mineral compositions are presented in table 1 .

Locations of the barometric and thermometric reactions in PT diagrams have been calculated using TWQ (e.g., Lieberman and Petrakakis 1991; Mäder et al. 1994), with the internally consistent data set of Berman (1988 and 1990) supplemented with consistent thermodynamic properties for amphiboles (Mäder et al. 1994). Activity models used are Fuhrman and Lindsley (1988) for plagioclase, Berman (1990) for garnet, McMullin et al. (1991) for biotite, and Mäder et al. (1994) for amphiboles. For clino- and orthopyroxene simple ideal two-site solution was assumed.

Results. Calculated PT estimates for the Transition Zone and the Triangle shear zone obtained

\begin{tabular}{|c|c|c|c|c|c|c|c|c|c|c|c|c|c|c|}
\hline Sample No & $92 / 122$ & $93 / 528$ & L91-62H & 2B L93-2 & 24 L93- & & 93-32 L93 & -33 & L93-B 92 & $92 / 122$ & $93 / 528$ & L91-62B & L93-32 & L93-33 \\
\hline $\begin{array}{l}\text { Mineral } \\
\text { Phase }\end{array}$ & \multicolumn{9}{|l|}{ Garnet } & \multicolumn{5}{|c|}{ Plagioclase } \\
\hline $\mathrm{SiO}_{2}$ & 37.64 & 38.02 & 37.43 & 37.90 & 37.96 & 96 & 38.15 & 38.25 & 37.63 & 58.49 & 57.63 & 63.26 & 55.69 & 63.26 \\
\hline $\mathrm{TiO}_{2}$ & .03 & .03 & .02 & & 00 & 01 & .06 & .03 & .01 & .02 & .00 & .01 & .01 & .01 \\
\hline $\mathrm{Al}_{2} \mathrm{O}_{3}$ & 20.97 & 21.56 & 21.63 & 21.5 & 20. & & 21.08 & .21 & 21.84 & 26.79 & 27.49 & 24.21 & 28.42 & 24.21 \\
\hline $\mathrm{FeO}$ & 30.75 & 29.47 & 33.51 & 30.5 & 32. & & 27.27 & .32 & 31.22 & .09 & .33 & .17 & .42 & .17 \\
\hline $\mathrm{MnO}$ & 2.40 & 2.10 & 1.47 & 1.8 & 83 & 46 & 2.29 & .81 & 1.61 & .01 & .00 & .01 & .01 & .01 \\
\hline $\mathrm{MgO}$ & 2.72 & 4.02 & 4.82 & 4.9 & 93 & 98 & 4.77 & 47 & 5.92 & .00 & .00 & .01 & .00 & .01 \\
\hline $\mathrm{CaO}$ & 6.73 & 5.20 & 2.28 & 3.3 & 7. & 63 & 6.74 & .53 & 2.08 & 8.29 & 8.84 & 5.70 & 10.38 & 5.70 \\
\hline $\mathrm{Na}_{2} \mathrm{O}$ & .01 & .00 & .01 & .0 & 04 & 01 & .01 & .01 & .01 & 6.84 & 6.43 & 8.07 & 5.36 & 8.07 \\
\hline $\mathrm{K}_{2} \mathrm{O}$ & .00 & .01 & .00 & & 01 & 01 & .00 & .00 & .00 & .13 & .05 & .43 & .30 & .43 \\
\hline Total & 101.25 & 100.41 & 102.17 & $\begin{array}{ll}7 & 100.1\end{array}$ & 13100 & & $00.37 \quad 101$ & $.63 \quad 1$ & 100.32 & 100.66 & 100.77 & 101.87 & 100.59 & 101.87 \\
\hline Sample No & L91-62B & L93-28 & L93-32 I & L93-33 & L93-28 & L93-32 & 32 L91-62B & L93-24 & 24 L93-33 & 3 L93-B & $92 / 122$ & $293 / 528$ & L93-28 & L93-32 \\
\hline $\begin{array}{l}\text { Mineral } \\
\text { Phase }\end{array}$ & Orthopy & roxene & & & Clinopy & roxene & e Biotite & & & & Hornble & lende & & \\
\hline $\mathrm{SiO}_{2}$ & 49.90 & 49.46 & 51.57 & 49.90 & 51.29 & 51.03 & 35.27 & 35.72 & 35.27 & 35.78 & 42.00 & 46.19 & 39.74 & 41.52 \\
\hline $\mathrm{TiO}_{2}$ & .07 & .01 & .06 & .07 & .01 & .25 & 5.24 & 4.81 & 5.24 & 4.79 & 1.42 & 1.06 & .11 & 2.22 \\
\hline $\mathrm{Al}_{2} \mathrm{O}_{3}$ & 1.99 & .77 & 1.23 & 1.99 & 1.23 & 2.44 & 13.82 & 15.46 & 13.82 & 15.71 & 11.77 & 9.94 & 12.38 & 12.19 \\
\hline $\mathrm{FeO}$ & 33.55 & 39.35 & 28.30 & 33.55 & 18.57 & 10.95 & 23.95 & 20.10 & 23.95 & 18.74 & 22.34 & 17.10 & 26.35 & 16.73 \\
\hline $\mathrm{MnO}$ & .24 & .14 & .83 & .24 & .06 & .33 & .04 & .06 & .04 & .07 & .29 & .24 & .02 & .17 \\
\hline $\mathrm{MgO}$ & 14.58 & 10.26 & 17.72 & 14.58 & 8.25 & 12.06 & 8.42 & 10.16 & 8.42 & 10.76 & 7.41 & 10.75 & 4.72 & 9.75 \\
\hline $\mathrm{CaO}$ & .32 & .79 & .53 & .32 & 21.08 & 21.42 & .02 & .00 & .02 & .02 & 10.79 & 10.26 & 11.14 & 11.34 \\
\hline $\mathrm{Na}_{2} \mathrm{O}$ & .01 & .01 & .01 & .01 & .33 & .41 & .06 & .01 & .06 & .09 & 1.76 & 1.35 & 1.16 & 1.23 \\
\hline $\mathrm{K}_{2} \mathrm{O}$ & .01 & .00 & .01 & .01 & .00 & .00 & 9.14 & 9.54 & 9.14 & 9.46 & .50 & .27 & 2.18 & 1.88 \\
\hline Total & 100.67 & 100.79 & 100.26 & 100.67 & 100.82 & 98.89 & 95.96 & 95.86 & 95.96 & $6 \quad 95.42$ & 98.28 & 97.16 & 97.80 & 97.03 \\
\hline
\end{tabular}
in this study are combined with results for the Triangle shear zone reported by Kamber et al. (1995) in table 2, where samples are listed from NW to SE along the profile. Apparent PT conditions were calculated from intersections of barometric and thermometric reactions where possible. $T$ for samples with no information on $\mathrm{P}$ was calculated at

Table 1. Mineral Compositions Used for Thermobarometry 
Table 2. Results of Thermobarometry

\begin{tabular}{|c|c|c|c|c|c|c|c|c|c|}
\hline Thermometer & $\begin{array}{l}\text { Grt-Bt } \\
{[1]\left({ }^{\circ} \mathrm{C}\right)}\end{array}$ & $\begin{array}{l}\text { Grt-Cpx } \\
{[2]\left({ }^{\circ} \mathrm{C}\right)}\end{array}$ & $\begin{array}{l}\text { Grt-Hbl } \\
{[3]\left({ }^{\circ} \mathrm{C}\right)}\end{array}$ & $\begin{array}{l}\text { Grt-Opx } \\
{[4]\left({ }^{\circ} \mathrm{C}\right)}\end{array}$ & $\begin{array}{c}\text { Opx-Cpx } \\
{[5]\left(C^{\circ}\right)}\end{array}$ & & & & \\
\hline & & & & & & $\begin{array}{l}\text { Grt-Cpx- } \\
\text { Pl-Qtz [6] }\end{array}$ & $\begin{array}{l}\text { Grt-Opx- } \\
\text { Pl-Qtz [7] }\end{array}$ & $\begin{array}{l}\text { Grt-Hbl- } \\
\text { Pl-Qtz [8] }\end{array}$ & $\begin{array}{l}\text { Cpx-Hbl- } \\
\text { Pl-Qtz [9] }\end{array}$ \\
\hline Barometer & & & & & & $(\mathrm{kb})$ & $(\mathrm{kb})$ & $(\mathrm{kb})$ & $(\mathrm{kb})$ \\
\hline \multicolumn{10}{|l|}{ Sample } \\
\hline $93 / 528$ & & & 650 & & & & & 5.6 & \\
\hline $92 / 122$ & & & 680 & & & & & 6.8 & \\
\hline L93-B & 815 & & & & & & & & \\
\hline $92 / 130^{a}$ & 775 & & & & & & & & \\
\hline $92 / 132^{a}$ & 860 & & & & & & & & \\
\hline L93-24 & 825 & & & & & & & & \\
\hline L93-28 & & 740 & 800 & 570 & 930 & & & & \\
\hline L91-62B & 825 & & & & & & & & \\
\hline $92 / 085^{a}$ & 815 & & & & & & & & \\
\hline $92 / 134^{a}$ & & & & & 760 & & & & 8.3 \\
\hline L93-32 & & 740 & 750 & 670 & 840 & 7.9 & 6.8 & 8.2 & 9.6 \\
\hline $92 / 084^{a}$ & & 700 & 705 & 550 & 680 & 7.7 & 6.7 & 7.8 & 7.4 \\
\hline L93-33 & 900 & & & 680 & & & 6.8 & & \\
\hline $92 / 045^{a}$ & 815 & & & & & & & & \\
\hline $92 / 086^{a}$ & & & 760 & 570 & & & 5.3 & 8.0 & \\
\hline
\end{tabular}

Note. For samples where a $\mathrm{P}$ estimate was impossible, $\mathrm{T}$ was calculated at an average $\mathrm{P}$ of $8.0 \mathrm{~kb}$. Numbers in [brackets] refer to reactions described in text.

${ }^{a}$ PT estimates for samples from Kamber et al. (1995).

the average $\mathrm{P}$ of $8.0 \mathrm{~kb}$. However reactions $[1,2,3,4]$ are nearly P-independent over a range of 4 to 10 $\mathrm{kb}$. Comparison of results from the different thermometers and barometers shows that reactions involving orthopyroxene constantly yield aberrantly low PT values. Similar observations have been mentioned by other studies, e.g. Fitzsimons and Harley (1994) or Mäder et al. (1994). The reason for the low temperatures calculated with reaction [4] is subject to some debate. On the one hand they can reflect post-peak Fe-Mg reequilibration, in which case deduced pressures must also be regarded as minima (e.g., Harley 1989 or Fitzsimons and Harley 1994). On the other hand they might be the result of an inadequacy of thermodynamic end-member data and mixing models (Berman and Aranovich 1993). We therefore prefer to omit the results of reactions $[4,5,7]$ from the interpretation. Both pressure and temperature can then be described as being virtually constant $\left(800^{\circ} \mathrm{C}\right.$ at $\left.8 \mathrm{~kb}\right)$ over the southeastern two-thirds of the section. Only the northernmost part (figure 2) shows a significant decrease in $\mathrm{T}$ by $150^{\circ} \mathrm{C}$ and $\mathrm{P}$ by $2.5 \mathrm{~kb}$. Together with structural and geochronological data, this result is discussed in the final section of this paper.

\section{Structural Geology}

Structures in the study area have been recorded in detail at 76 stations along the profile which has been divided into seven sections, each characterized by distinctive structures and/or rock types. A minimum of five measurements of foliation and lineation orientations were measured at each station (figure 3), and best fits to poles of foliation and lineations were found at each station from the maximum eigenvector of the distribution. These were used to calculate the apparent dips shown on the profile in figure 4 and to plot the true dips shown in figure 5.

1. Northern Marginal Zone Section (0-6.3 km along the profile). Structures are relatively simple: A variably developed foliation and gneissic banding dip steeply to the southeast and a down-dip mineral stretching lineation is observed on some foliation surfaces (figure 3). The overall fabric is $S$ or $\mathrm{S}>\mathrm{L}$. This fabric and fabric orientation are typical of most parts of the Northern Marginal Zone (Rollinson and Blenkinsop 1995).

2. Maranda Section $(6.3-8.4 \mathrm{~km})$. The orientation of foliation and gneissic banding in this section varies from moderate SE dips at the northern and 


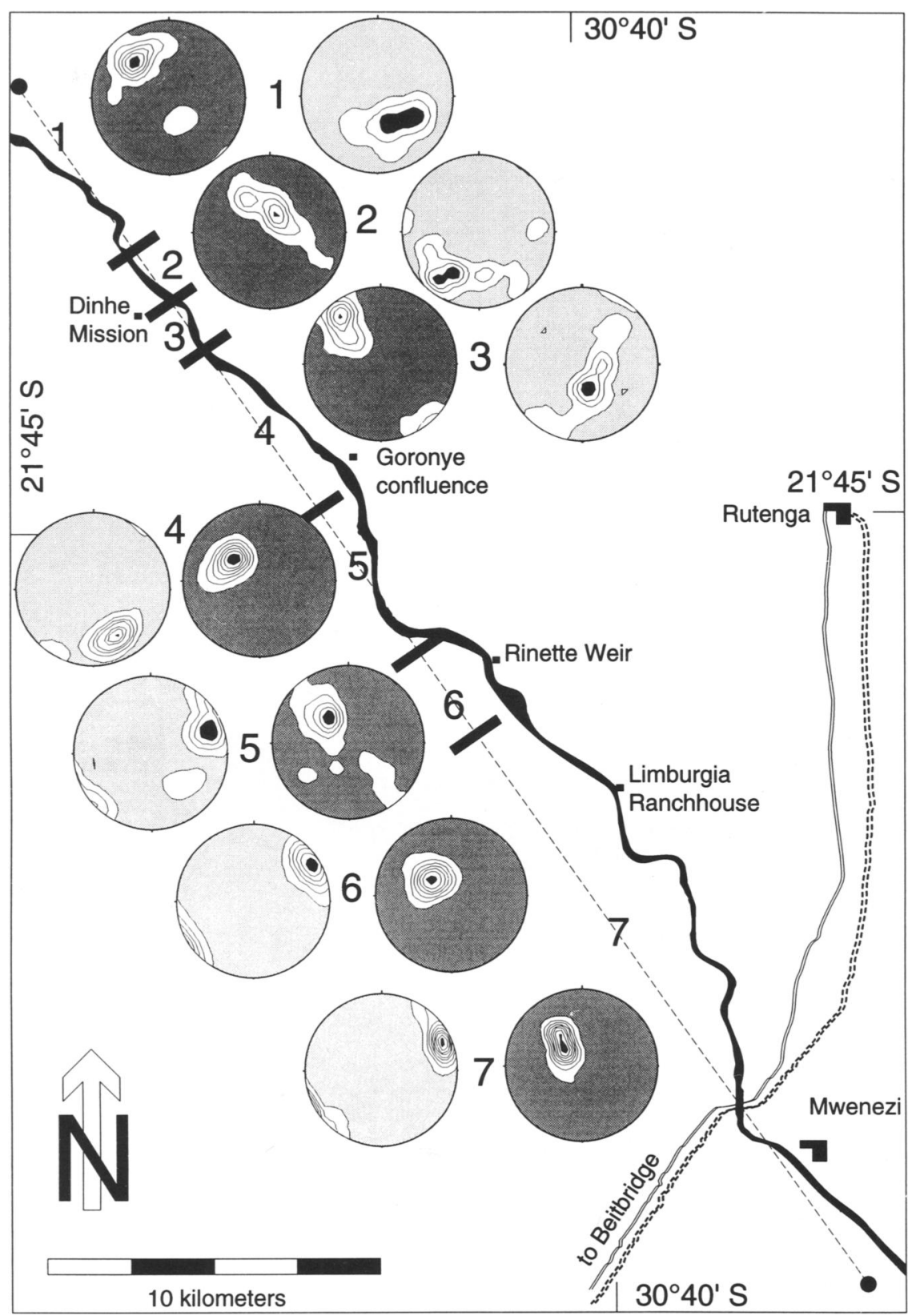

Figure 3. Stereoplots for the seven structural sections ( 1 to 7 ) along the profile. Poles of foliation are given on stereoplots with dark shading, lineation on stereoplots with light shading. Lower hemisphere, equal area projections; contouring on the projection sphere. Shaded areas are pole-free; black areas are maximum densities of poles. Contours in multiples of a uniform distribution (MUD); contour intervals $3 \times$ MUD. Numbers of poles to foliations and lineations in each section: (1) 45,24 ; (2) 56,48 ; (3) 49, 47; (4) 45,$44 ;(5) 78,41 ;(6) 26,25 ;(7) 76$, 74. southern ends of the section to gentle SW dips in the center (figures 4 and 5). Lineations plunge gently southeast or east (figure 3). The fabric is $\mathrm{S}>\mathrm{L}$. Minor asymmetric folds are quite common in this section, verging to the northwest and plunging gently to the southwest (figure 6a).

3. Dinhe Mission Section $(8.4 \mathrm{~km}-9.8 \mathrm{~km})$. Foliation and gneissic banding in this section dip steeply southeast, and lineations plunge moderately to steeply southwest (figure 3). The foliation in this section is noticeably more intense than in the previous sections, and the gneisses have a characteristic pink color. The fabric is $\mathrm{S}>\mathrm{L}$ to L-S.

\section{South of Dinhe Mission Section (9.8-15.8}

km). Foliation and gneissic banding dip moderately southeast, and although most carry a downdip lineation, there are a few lineations plunging gently southwest (figure 3). The fabric is $\mathrm{S}>\mathrm{L}$. A few minor folds plunge gently southeast or east (figure $6 b$ ).

5. Rinette Weir Section $(15.8-21 \mathrm{~km})$. Foliation and gneissic banding dip both to the southeast and northwest, and lineations are clearly divided into two groups: one plunges gently southeast, and the other plunges gently northeast (figure 3). Lineations of either group may occur on foliations of any orientation. The fabric is generally $\mathrm{S}>\mathrm{L}$.

6. Rinette Weir-Limburgia Ranch section (21-24 




Figure 4. Profile showing lithological changes from northwest to southeast. Apparent dips were calculated from a minimum of five structural measurements at each station. Note different scale of lowermost segment.

Figure 5. Plot of true dip along the profile; northwest-plunging dips are designated by negative values. Line connects site average values /solid symbols) determined by eigenvector analysis.

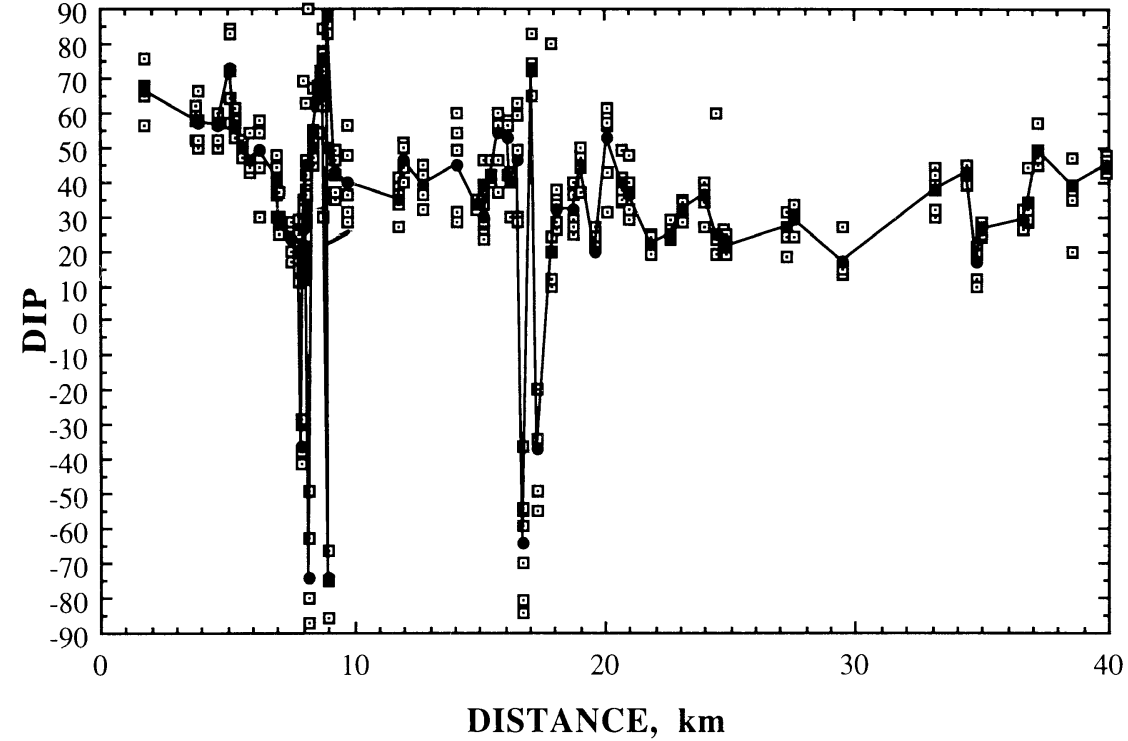






Figure 6. Stereoplots of fold axes of minor folds, from section $2(a)$, section $4(b)$, and section $7(c)$. Lower hemisphere equal area projections.

km). Foliation and gneissic banding have very consistent moderate dips to the southeast (figures 3,4 , and 5). Sub-horizontal northeast or southwesttrending lineations are strongly developed, and the fabric is $\mathrm{S}>\mathrm{L}$.

7. Triangle Shear Zone Section (24-43 km). The orientations of foliation, gneissic banding, and lineations are similar to those in the previous section (figure 3). However, major differences are observed in the fabric, which becomes LS. Minor fold axes plunge gently northeast (figure $6 c$ ). Abundant shear sense indicators are seen in the form of rotated $s$ and d porhyroclasts and rolling structures all indicating unambiguous dextral shear sense. The grain size is reduced by half. The gneisses have been recystallized into mylonites.
There is an overall decrease in dip of foliation and gneissic banding from the northwest to the southeast. The changes in dip noted in the Dinhe Mission and Rinnette Weir sections can best be interpreted as two kilometer-scale, asymmetric folds, with long southeast-dipping limbs and short, northwest-dipping limbs. These folds therefore verge to the northwest. These structures are clearly represented on the plot of true dip along the profile seen in figure 5, where northwest dips are designated by negative values. Abrupt changes in dip occur within the larger structures and can be attributed to minor folds on the larger structures. In several places along the profile, thin veins of pegmatite or granite dipping steeply to the southeast cut the foliation and gneissic banding. These veins may be undeformed and planar or deformed into ptygmatic folds. Their orientation is approximately axial planar to the mesoscopic and macroscopic folds.

Mineral stretching lineations in the study area show a clear bimodal distribution between moderate southeast plunges and gentle, southwestnortheast plunges. The southeast-plunging lineations are associated with southeast-dipping foliations in L-S or S $>\mathrm{L}$ fabrics that have no indication of non-coaxial strain. We therefore interpret the southeast-plunging lineations and southeastdipping foliations as evidence for plane to slightly oblate strain with an extension direction inclined to the northwest. This deformation has affected most of the rocks in the first and third sections of the profile. Southwest or northeast-plunging lineations are observed in sections 2 and 5 where the foliation and gneissic banding define northwest-verging folds. The lineations are parallel to the fold axes. These structures suggest uplift of the southeast part of the profile over the northwest on two major folds with hinges in sections 2 and 5, and northeast-southwest subhorizontal extension throughout sections 2, 4, 5, and 6.

Non-coaxial strain and grain size reduction to form mylonites is observed throughout section 7, the Triangle shear zone. Subhorizontal northeast extension is shown by strong lineations. Some of the lineations may be fold axes in the shear zone, which are also approximately parallel to the shear direction in these highly strained rocks; the majority of lineations are however extension lineations associated with strike-slip simple shear. The shear sense is unambiguously dextral.

In summary, we interpret the structures to show extension inclined toward the northeast direction, extension parallel to fold axes of folds that uplift the southeast of the section, and dextral shear. We 
argue that these deformation patterns developed coevally for two reasons. First, the lineations form distinct, tightly clustered groups that occur together in the profile: there is no evidence of superimposed deformation that would have dispersed the clusters. No intermediate orientations are observed between the two groups, and on a small scale, there is no evidence for deformed lineations. Second, no lineation is observed cross-cutting another lineation; any foliation surface has only one distinct lineation. The single deformation consisted of subvertical extension and dextral simple shear and can therefore be called transpression (Sanderson and Marchini 1984), although it is unusual in that the extension direction of the coaxial component is inclined, and the shear plane of the strike-slip component dips gently to the southeast. We conclude that the reason for two distinct lineations is that the strain is partitioned into thrust and strike-slip components.

The gentle dip of the Triangle shear zone is quite remarkable for strike-slip shear zones, which are commonly sub-vertical. The Triangle shear zone (as well as the Transition Zone) is a continuous 30 to $50 \mathrm{~km}$ wide feature of the southern margin of the Northern Marginal Zone (figure 1). The gentle dip of the shear zone means that low shear stress is resolved on the shear planes in a strike-slip stress regime. This requires us to consider whether the shear zone was tilted to its present orientation after strike-slip deformation. We can rule out this possibility from the distribution of pressures within the shear zone (table 2). No increase in pressure is recorded over at least a $20 \mathrm{~km}$-wide section. Tilting from a vertical orientation to a dip of $40^{\circ}$ should create a $15 \mathrm{~km}$ difference $(20 \cos 40)$ in apparent depth. We suggest that the unusual orientation of the shear zone is permitted by the very high temperatures of deformation, under which even the low resolved shear stress in a strike-slip stress regime could cause large strain due to low viscosity. We have no direct knowledge of the stress tensor, however.

\section{Geochronology}

Kamber et al. (1995) have dated the main deformation and related granulite-grade metamorphism in the Triangle shear zone /chiefly section 7 of our study area) using the $\mathrm{Pb} / \mathrm{Pb}$ garnet and ${ }^{39} \mathrm{Ar}-{ }^{40} \mathrm{Ar}$ hornblende chronometers. In addition they presented a seven point $\mathrm{Sm} / \mathrm{Nd}$ mineral isochron. Integrating the results of all chronometers they concluded that the $2.04 \mathrm{Ga} \mathrm{Pb} / \mathrm{Pb}$ garnet dates reflect the time during or slightly before the metamorphic peak, and that the main strike-slip deformation occurred at $2.00 \mathrm{Ga}$, followed by rapid cooling after near-isothermal decompression.

We have tried to test the contemporaneity of deformation along the profile first described and observed in the field by dating minerals with a well-constrained structural significance and comparing their date with the $2.00 \mathrm{Ga}$ age of strike-slip movement for section 7 (the Triangle shear zone).

Within sections 1 to 4 metamorphic hornblende is the only mineral that unequivocally forms a growth lineation occurring in the narrow range of lithologies encountered. We have selected five samples of amphibolite for ${ }^{39} \mathrm{Ar}-{ }^{40} \mathrm{Ar}$ hornblende dating, indicated on figure 2. Three samples (92/ $122,93 / 528,93 / 530$ ) display a strong southeastplunging growth-lineation, the remaining two (93/ 529 and 93/533) show a distinctive sub-horizontal lineation of the same kind. In addition to green metamorphic hornblende, breakdown of orthopyroxene and plagioclase produced metamorphic sphene in sample $93 / 529$, which has a $\mathrm{Pb} / \mathrm{Pb}$ age of $1969 \pm 12 \mathrm{Ma}$ (Frei and Kamber 1995).

In order to assess the extent of the $2.0 \mathrm{Ga}$ thermal disturbance farther north of the study area, magmatic brown biotite from two samples (93/109 and $92 / 113$ ) of virtually undeformed $2637 \pm 19 \mathrm{Ma}$ old enderbite (Berger et al. 1995) occurring $\approx 10 \mathrm{~km}$ north of Dinhe Mission have been analyzed for $\mathrm{Rb} / \mathrm{Sr}$. In the rapidly cooled Central Zone of the Limpopo Belt, this chronometer (Barton and van Reenen 1992) yields ages 30 m.y. younger (1970 Ma) than peak metamorphism (Barton et al. 1994 and Kamber et al. 1995), while the larger age lag (130 m.y.) found by van Breemen and Dodson (1972) at Tods Quarry implies a slower cooling for what we argue is a separate block (i.e., the Northern Marginal Zone s.s.).

Analytical Procedure: ${ }^{39} \mathrm{Ar} \mathbf{-}^{40} \mathrm{Ar}$. Hornblendes were pre-separated magnetically and gravimetrically; $10-15 \mathrm{mg}$ of each were handpicked to achieve visual purity of $\approx 100 \%$. The samples were step-heated in a double-vacuum resistance oven connected to a $\mathrm{MAP}^{\circledR}$ 215-50 mass spectrometer. Data listed in table 3 were corrected for mass spectrometer background and discrimination $10.13 \%$ / amu favouring heavy masses). Table 3 is available from The Journal of Geology free of charge upon request.

Analytical Procedure: $R \boldsymbol{R}$ /Sr. Dissolution of visually pure biotite separates, chemical extraction and analyses of $\mathrm{Rb}$ and $\mathrm{Sr}$ followed routine lab procedures (e.g., Mkweli et al. 1995). Data listed in table 4 are corrected for fractionation, spike and blank.

Results. Ar-Ar step heating results are listed in 
Table 4. Rubidium and Strontium Data

\begin{tabular}{|c|c|c|c|c|c|c|c|c|c|c|}
\hline Sample & Fraction & $\begin{array}{c}\mathrm{Rb} \\
{[\mathrm{ppm}]}\end{array}$ & $2 \mathrm{SE} \%$ & $\begin{array}{c}\mathrm{Sr} \\
{[\mathrm{ppm}]}\end{array}$ & $2 \mathrm{SE} \%$ & ${ }^{87} \mathrm{Rb} /{ }^{86} \mathrm{Sr}$ & $2 \mathrm{SE} \%$ & ${ }^{87} \mathrm{Sr} /{ }^{86} \mathrm{Sr}$ & $2 \mathrm{SE} \%$ & $\begin{array}{l}\text { Age } \\
(\mathrm{Ma})\end{array}$ \\
\hline $93 / 109$ & biotite & 299.81 & .5 & 48.81 & .049 & 18.639 & .5 & 1.208272 & .0022 & \\
\hline $93 / 109$ & whole rock & 41.92 & 1.0 & 372.58 & .079 & .326 & 1.0 & .716496 & .0052 & $1866 \pm 9$ \\
\hline $92 / 113$ & biotite & 517.12 & .5 & 9.02 & .019 & 292.328 & .5 & 8.504019 & .0076 & \\
\hline $92 / 113$ & whole rock & 122.38 & 1.0 & 194.8 & .047 & 1.829 & 1.0 & .770159 & .0048 & $1850 \pm 9$ \\
\hline
\end{tabular}

table 3 and are graphically displayed on figures 7 and 8 . None of the datasets can be fitted with a statistically flawless isochron. The spectra produced from all five samples have low temperature steps (thermocouple reading $<1080^{\circ} \mathrm{C}$ ) with heterogeneous $\mathrm{K} / \mathrm{Ca}$ ratios typical of hornblende intergrown with other $\mathrm{Ca}$ - and/or K-bearing phases. The remaining gas is characterized by constant $\mathrm{K} /$ $\mathrm{Ca}$ ratios, and the age differences between individual steps become small. Although not all the steps overlap in error, the flat portions of the spectra ("pseudoplateaus") may be interpreted as plateau ages. Sample 93/528 has a constant K/Ca ratio in the higher temperature steps; nevertheless the step ages never approach a flat portion in the spectrum. We note that the $\mathrm{K} / \mathrm{Cl}$ ratio is not constant; as decreptitation of fluid inclusions may be discarded at the high extraction temperatures, it is tempting to relate the high $\mathrm{Cl}$ concentration to the degassing of a trace phase (tremolite-actinolite or chlorite?) with a younger age.

These five "plateau ages" show a spread in age of $68 \mathrm{~m}$.y., which can neither be attributed to the geographic distribution of the samples nor to the lineation they define. Two samples, 93/529 and 93/ 530 , have ages of $2.00 \mathrm{Ga}$ identical with the ages on section 7 obtained by Kamber et al. (1995), whereas the other three $(92 / 122,93 / 528$ and 93/ 533 ) are significantly younger.

The following three explanations can be envisaged: (1) All the ages correspond to growth ages at metamorphic temperatures of $\approx 600^{\circ} \mathrm{C}$. This either means a long duration of a single metamorphic event or a close succession of two events reaching approximately the same PT conditions. Taking into account that all the five samples carry a hornblende growth lineation and no intermediate or deformed lineations are found, this also implies two tectonic events with identical kinematics, which seems improbable.

2) The transpression was a single event that occurred at $1.95 \mathrm{Ga}$. Three samples give a correct age, two have excess Ar. This is not ruled out by the Ar data alone (possibility of a false excess plateau,
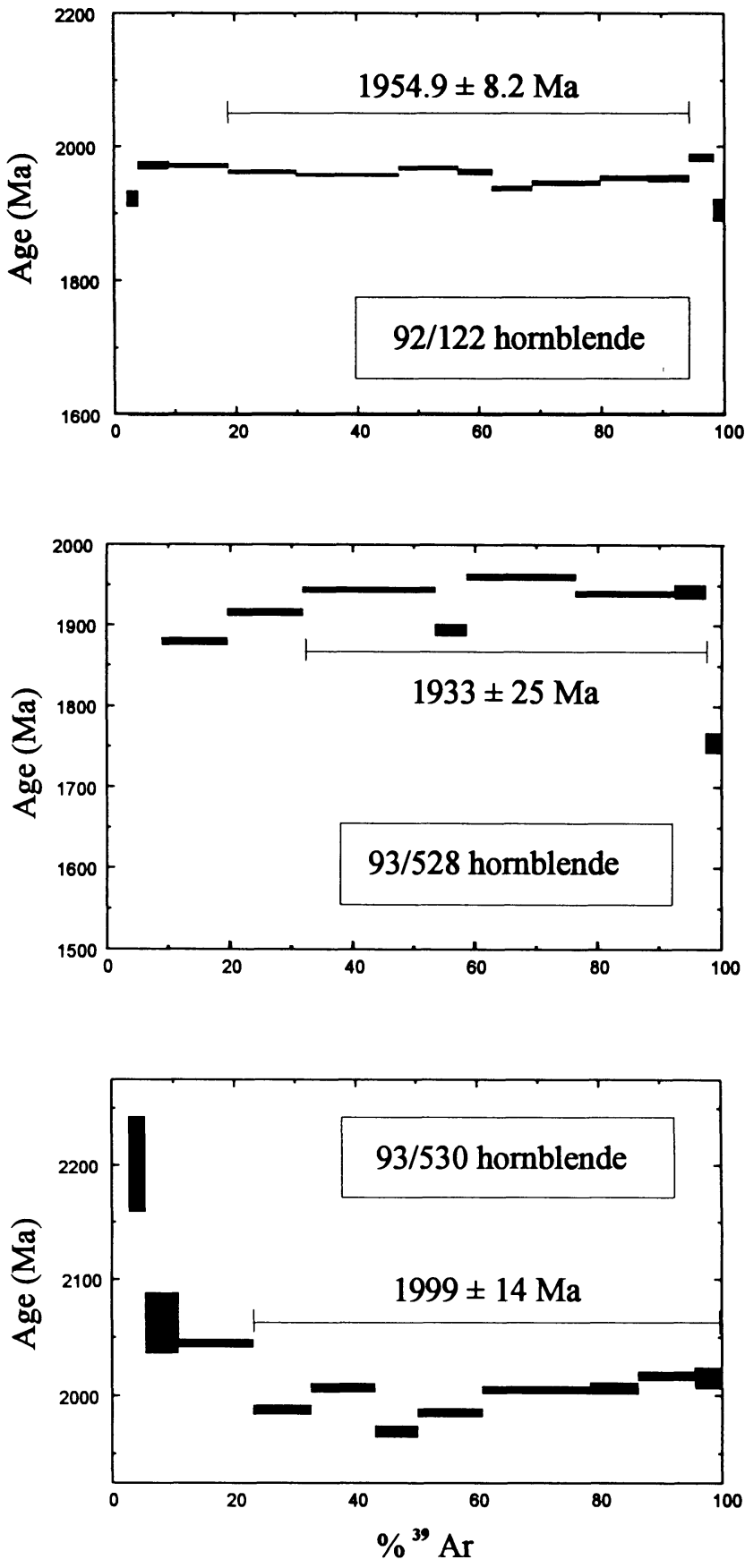

Figure 7. ${ }^{39} \mathrm{Ar}-{ }^{40} \mathrm{Ar}$ age spectra for hornblendes defining a down-dip growth lineation. 

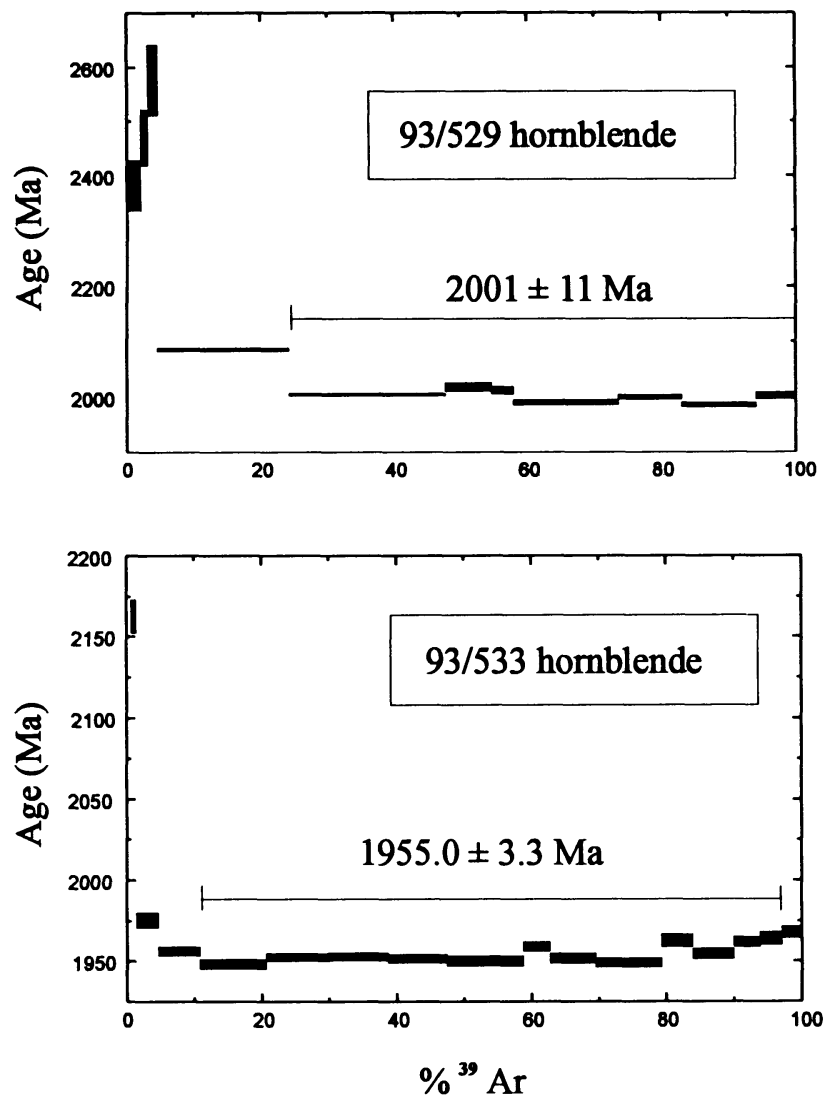

Figure 8. ${ }^{39} \mathrm{Ar}-{ }^{40} \mathrm{Ar}$ age spectra for hornblendes defining a sub-horizontal growth lineation.

von Blankenburg and Villa 1988), but by comparison with a $1.97 \mathrm{Ga} \mathrm{Pb} / \mathrm{Pb}$ sphene post-peak cooling age (Frei and Kamber 1995).

3) The transpression was a single event that occurred at $2.00 \mathrm{Ga}$. Two hornblendes give a peak age in agreement with the ages from the Triangle shear zone, the sphene and three hornblendes give cooling ages. This interpretation presumes no geographic or structural control of the age range and, further, pure diffusional Ar loss during uniform slow cooling. This interpretation is justified by the proximity of the amphibolite samples. Moreover the lack of microstructural/mineralogical recrystallization or phyllosilicate alteration of the hornblendes suggests that they cooled in a fluid-absent, deformationally static environment, such that volume-diffusion most likely governed post-2.00 Ga ${ }^{40} \mathrm{Ar}$ loss from minerals (instead of reaction or recrystallization, which are much faster processes than volume-diffusion and would therefore completely overwhelm it). Finally, this interpretation presumes chemical dependence of diffusional closure temperatures $\left(T_{C}\right)$ among the hornblendes. In terms of basic crystal chemistry, such dependence is expected since the flexibility of the amphibole structure in accomodating diverse compositions translates into variance in overall metal-oxygen bond length/strength (Hawthorne 1983; Lee 1993) and probably in Ar volume-diffusion kinetics also (Dahl 1994, 1995). Even modest variance in diffusion kinetics (and thus mean $T_{C}$, Dodson 1973) ought to be magnified as plateau-age differences in adjacent slowly cooled (i.e., $\leq 2^{\circ} \mathrm{K} / \mathrm{m}$.y.) amphiboles-all other age-controlling factors equal.

Five near-plateau 2.00-1.93 Ga ages, obtained in the chemically diverse hornblendes from adjacent amphibolites (table 3, figures 7 and 8 ) are inversly correlated with "ionic porosity" $Z$. This parameter (Dowty 1980; Fortier and Giletti 1989), defined as the percentage of unit cell not occupied by ions, is a first-order approximation for the overall length and strength of the ionic bonds in a crystal and is thus a good proxy for the resistance that a given lattice will exert on the diffusion of Ar. The quantitative diffusivity-porosity model of Fortier and Giletti (1989) has been extended by Dahl (1994, $1995)$ to predict diffusion parameters $\left(E\right.$ and $\left.D_{O}\right)$ for Ar in hornblendes as simple functions of $Z$. According to Dahl, there should be an inverse correlation between porosity and closure temperature $T_{C}$ such that each $1 \%$ (absolute) difference in $Z$ among natural hornblendes translates into $37 \pm 2 \mathrm{~K}$ and $37 \pm 2 \mathrm{~m} . \mathrm{y}$. differences in $T_{C}$ (irrespective of $d T /$ $d t)$ and age $(d T / d t=1 \mathrm{~K} / \mathrm{m} . \mathrm{y}$.$) , respectively. In$ our samples calculated values range from 36.7 to $37.8 \%$ (table 5), i.e., Dahl's model predicts $41 \pm 9$ $\mathrm{K}$ difference in mean $T_{C}$.

The inverse correlation between near-plateau age and $Z$ is shown in figure $9\left(r^{2}=0.67\right)$, where the crosses bracket age- $Z$ uncertainties. The crystal-chemical rationale for the trend in figure 9 is simply that "tighter" (i.e. lower Z) hornblende lattices inhibit diffusional loss of Ar by virtue of shorter/stronger metal-oxygen bonds, such that older ${ }^{39} \mathrm{Ar}-{ }^{40} \mathrm{Ar}$ closure ages are preserved upon cooling, whereas the more "porous" hornblendes close to Ar diffusion later in the cooling history. No such correlations were found in separate plots of age versus $M g \#$, A-site occupancy or Tschermak's component $\left(r^{2} \leq 0.13\right)$, however, suggesting that none of these parameters, individually, is an effective monitor of Ar diffusivity. The slope of $T_{C}$ $(Z)$-age correlation of figure 9 translates into a model cooling rate of $0.7_{-0.3}^{+0.9} \mathrm{~K} / \mathrm{m} . \mathrm{y}$. Within error, this agrees with an independent cooling rate of 1.0 $\pm 0.5 \mathrm{~K} / \mathrm{m} . \mathrm{y}$. estimated for the study area from garnet (2.00 Ga, $\mathrm{Pb} / \mathrm{Pb}$, Kamber et al. 1995), sphene (1.97 Ga, Pb/Pb, Frei and Kamber 1995) and biotite (1.86 Ga, Rb/Sr, this study table 4 ). Thus the in- 
Table 5. Composition, Unit Cell Parameters, and Ionic Porosities of Dated Amphibole Samples

\begin{tabular}{|c|c|c|c|c|c|c|c|c|c|c|}
\hline Sample & $\mathrm{Si}$ & $\mathrm{Ti}$ & $\mathrm{Al}$ & \multicolumn{2}{|c|}{$\mathrm{Fe}^{+2}$} & $\mathrm{Mn}^{+2}$ & $\mathrm{Mg}$ & $\mathrm{Ca}$ & $\mathrm{Na}$ & $\mathrm{K}$ \\
\hline $92 / 122$ & $6.424(28)$ & $.159(10)$ & \multirow{2}{*}{$2.098(35)$} & & $.039(6)$ & \multirow{2}{*}{$1.742(36)$} & $1.774(18)$ & $.508(19)$ & $.097(7)$ \\
\hline $93 / 528$ & $6.735(77)$ & $.125(13)$ & & \multicolumn{2}{|c|}{$\begin{array}{l}2.830(40) \\
2.233(99)\end{array}$} & $.035(8)$ & & $1.682(87)$ & $.414(34)$ & $.062(6)$ \\
\hline $93 / 529$ & $6.656 \mid 60)$ & $.120(13)$ & $1.886(91)$ & \multicolumn{2}{|c|}{$2.420(56)$} & $.043(4)$ & \multirow[t]{2}{*}{$2.096(61)$} & $1.862(37)$ & $.346(29)$ & $.070(4)$ \\
\hline $93 / 530$ & $6.617(46)$ & $.172(7)$ & $1.776(54)$ & \multicolumn{2}{|c|}{$2.068(37)$} & $.034(4)$ & & $1.867(22)$ & $.462(22)$ & $.077(5)$ \\
\hline $93 / 533$ & $6.312(34)$ & $.226(10)$ & $2.082(37)$ & \multicolumn{2}{|c|}{$2.088(41)$} & $.030(6)$ & $2.456(36)$ & $1.892(15)$ & . $394(20)$ & $.274(13)$ \\
\hline Sample & Space group & \multicolumn{2}{|c|}{$\begin{array}{l}\text { Beta angle } \\
\left({ }^{\circ}\right)\end{array}$} & ( & \multicolumn{2}{|c|}{$\begin{array}{c}\mathrm{b} \\
(\AA)\end{array}$} & $\begin{array}{l}c \\
(\AA ̊) \\
(\AA)\end{array}$ & $\begin{array}{l}\text { Cell Vol } \\
(\AA)^{\wedge} 3\end{array}$ & $\begin{array}{c}\text { Ionic Porosity } \\
(\%)\end{array}$ & $\begin{array}{l}\text { Age } \\
\text { (Ma) }\end{array}$ \\
\hline $92 / 12$ & $\mathrm{C} 2 / \mathrm{M}$ & \multicolumn{2}{|c|}{$104.80(8)$} & $9.843(4)$ & \multicolumn{2}{|c|}{$18.088(9)$} & $5.321(5)$ & 915.92 & 37.8 & 1955 \\
\hline $93 / 528$ & $\mathrm{C} 2 / \mathrm{M}$ & \multicolumn{2}{|c|}{$104.46(9)$} & $9.827(4)$ & \multicolumn{2}{|c|}{$18.093|9|$} & $5.287(7)$ & 910.25 & 37.77 & 1933 \\
\hline $93 / 529$ & $\mathrm{C} 2 / \mathrm{M}$ & \multirow{2}{*}{\multicolumn{2}{|c|}{$\begin{array}{l}104.39(9) \\
104.34(8)\end{array}$}} & $9.867|8|$ & \multicolumn{2}{|c|}{$18.15(1)$} & $5.172(8)$ & 897.17 & 36.74 & 2001 \\
\hline $93 / 530$ & $\mathrm{C} 2 / \mathrm{M}$ & & & $9.818(4)$ & \multicolumn{2}{|c|}{$18.093(8)$} & $5.271(9)$ & 907.15 & 37.32 & 1999 \\
\hline $93 / 533$ & $\mathrm{C} 2 / \mathrm{M}$ & \multicolumn{2}{|c|}{$105.01(9)$} & $9.829(7)$ & \multicolumn{2}{|c|}{$18.080(9)$} & $5.331(8)$ & 915.04 & 37.42 & 1955 \\
\hline
\end{tabular}

Note. All analytical errors (in brackets) are given at 2-sigma level absolute. Chemical composition is normalised to 23 oxygen. Analyses were performed on aliquots of the same fractions used for dating. All ionic porosity values were calculated from compositional and $\left(24^{\circ} \mathrm{C}\right)$ unit cell data according to the conventions of Fortier and Giletti (1989); see also Dahl (1994 and 1995).

verse age- $Z$ trend observed for our hornblendes not only supports the independent conclusions about regional cooling history but also appears to confirm quantitatively the diffusivity-retentivityporosity model for Ar in hornblende. In contrast, no age- $Z$ pattern in hornblende was observed in the southeastern block (i.e., the Triangle shear zone), and farther south in the Central Zone of the Limpopo Belt biotites yield $\mathrm{Rb} / \mathrm{Sr}$ ages of $1.97 \mathrm{Ga}$, only $0.03 \mathrm{Ga}$ younger than the peak of metamorphism (Barton and van Reenen 1992; Kamber et al. 1995). Together, these data suggest much faster cooling to the south, which compresses the cooling-age interval below analytical resolution. Collectively, this evidence favors explanation 3 , above.

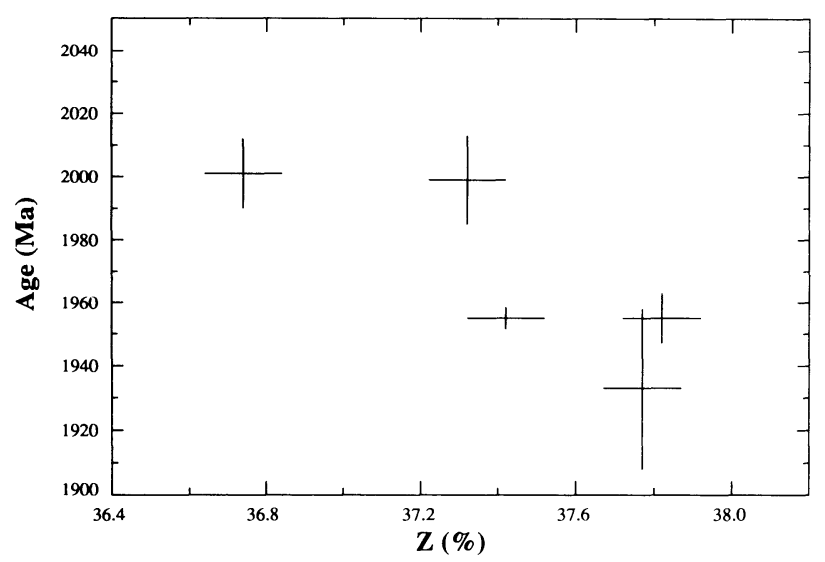

Figure 9. Plot of ${ }^{39} \mathrm{Ar}^{40} \mathrm{Ar}$ pseudo-plateau-age versus "ionic porosity" $(Z)$ for the dated amphibole samples. Crosses bracket age (figures 7 and 8$)$ and $Z(0.2 \%)$ uncertainties. For discussion see text.

\section{Summary and Conclusions}

Below are the data that document a major tectonometamorphism affecting the southern half of the Northern Marginal Zone at $2.00 \mathrm{Ga}$.

The Northern Marginal Zone can be subdivided into the Triangle shear zone, a Transition Zone, and the Northern Marginal Zone s.s. (Rollinson and Blenkinsop 1995). A structural profile through the Transition Zone well into the Triangle shear zone reveals the following deformation patterns: extension inclined toward the northeast; extension parallel to axes of folds that uplift the southeast of the section, and dextral shear. Lineations occur in distinct tightly clustered groups within the profile, and no evidence for either deformed or intermediate or cross-cutting lineations can be found. Thus a single deformation occurred, which consisted of subvertical extension and dextral shear, and can therefore be called transpression. A schematic diagram of this deformation is shown in figure 10 .

The contemporanity of deformation has been verified by dating hornblendes defining both types of growth lineations. The two least "porous" (Dahl 1994, 1995) hornblendes hold ${ }^{39} \mathrm{Ar}^{40} \mathrm{Ar}$ ages of 2.00 $\mathrm{Ga}$, identical with the results of Kamber et al. (1995) for dextral shear in the Triangle shear zone. The three more "porous" samples yield ages of 1.95-1.93 Ga, which by comparison with a 1.97 $\mathrm{Ga} \mathrm{Pb} / \mathrm{Pb}$ sphene post-peak cooling age (Frei and Kamber 1995) are regarded as cooling ages. Because the hornblendes show negligible evidence for mineralogical and microstructural recrystallization, this age spread probably reflects chemically dependent diffusivity differences upon uniform slow 


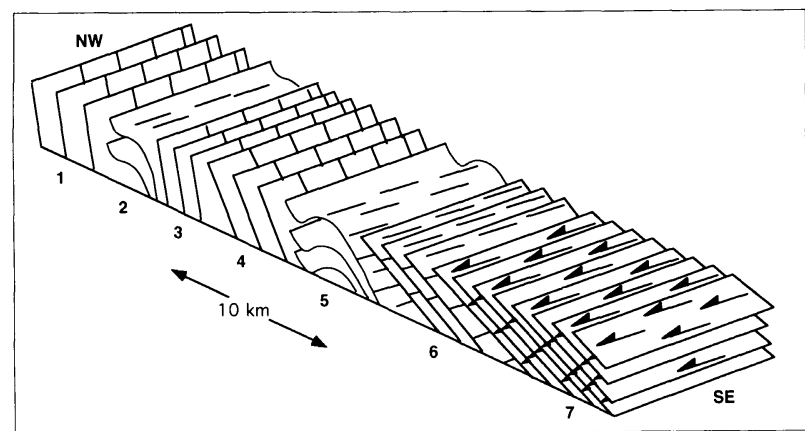

Figure 10. Schematic block diagram highlighting the major structural features. Overall decrease in dip of foliation from northwest to southeast, asymmetric northwest verging folds, bimodal distribution of streching lineations (one being subparallel to the foldaxes), and subhorizontal northeast extension along the Triangle shear zone mylonites. Numbers indicate structural sections as described in the text and shown on figure 3.

cooling; it can be quantitatively modeled using the concept of "ionic porosity," $Z$. In our samples, $Z$ ranges from $36.7 \%$ to $37.8 \%$; the extreme values correspond to a $41 \pm 9 \mathrm{~K}$ difference in the model $T_{C}$. This translates into a model cooling rate of $0.7_{-0.3}^{+0.9} \mathrm{~K} / \mathrm{m}$.y. Within error this agrees with the independent cooling rate of $1.0 \pm 0.5 \mathrm{~K} / \mathrm{m} . \mathrm{y}$. from garnet, sphene, and biotite.

Petrographic and geobarometric evidence support this kinematic picture. In the felsic gneisses, garnet and then orthopyroxene are found succesively toward the southeast of the profile, indicating uplift of the southeast in the order of 2.5 kbar along with an increase of peak temperature of $150^{\circ} \mathrm{C}$. In amphibolites, a distinction can be recognized between the cpx-free amphibolites in the northwest of the profile, and the two-pyroxene amphibolites in the southeast, also indicating uplift of the southeast.

$\mathrm{Rb} / \mathrm{Sr}$ biotite ages in the Central Zone to the south of this Proterozoic structure yield $1.97 \mathrm{Ga}$, only 30 m.y. younger than peak metamorphism (Barton and van Reenen 1992; Kamber et al. 1995).
A rapid cooling after isothermal decompression is in good agreement with PT loops published for this area (e.g., Windley et al. 1984), which can now be regarded as characterizing the Proterozoic rather than an Archean metamorphism. Contrasting cooling histories north and south of the studied Transition Zone following a $2.00 \mathrm{Ga}$ tectonometamorphism entirely independent of and superimposed on the late Archean event negates the hypothesis of slow cooling after a supposed $2.65 \mathrm{Ga}$ Tibetanstyle orogeny.

Existing models for the Limpopo Belt can be classified into those that do not recognize the importance of the strike-slip movement on the Triangle shear zone (e.g., Roering et al. 1992; De Wit et al. 1992; Windley et al. 1993) or those that attribute an incorrect Archean age to this deformation (e.g., McCourt and Vearncombe 1992; Treloar et al. 1992). None of the models has realized the important uplift of the Central Zone associated with this movement. This study indicates that no current model correctly describes both the tectonics and the timing of major deformation in the entire Limpopo Belt, which should therefore no longer be used as an example of late Archean modern-style plate tectonics.

\section{A C KNOWLEDGMENTS}

We would like to thank J. D. Kramers, M. Berger, S. Mkweli, K. Chisi, T. Mukulani, and Ch. Fedo for fruitful discussions both in the field and in the lab. Ar samples were kindly irradiated by M. Oddone, A. Hauser assisted with XRD. H. Rollinson, $\mathrm{J}$. Vearncombe and an anonymous referee are thanked for their reviews which helped to enhance the clarity of presentation. This work was supported by Schweizerischer National Fonds (grant 20-33975-92) and University of Zimbabwe research board (grant 3513). Finally BSK would like to thank the people living along the Mwenezi river for allowing him to penetrate "taboo" areas.

\section{REFERENCES CITED}

Barton, J. M., and Key, R. M., 1981, The tectonic development of the Limpopo Belt and the evolution of the Archean cratons in southern Africa, in Kröner, A., ed., Precambrian Plate Tectonics: Elsevier, Amsterdam, p. 185-212.

_; van Reenen D. D.; and Roering, C., 1990, The significance of $3000 \mathrm{Ma}$ granulite-facies mafic dikes in the central zone of the Limpopo Belt, southern Africa: Precamb. Res., v. 48, p. 299-308.

$\longrightarrow$, and $\longrightarrow$ 1992, The significance of $\mathrm{Rb}-\mathrm{Sr}$ ages of biotite and phlogopite for the thermal history of the Central and Southern Marginal Zones of the Limpopo Belt of southern Africa and the adjacent portions of the Kaapvaal Craton: Precamb. Res., v. 55, p. 17-31. 
Holzer, L.; Kamber, B.; Doig, R.; Kramers, J. D.; and Nyfeler, D., 1994, Discrete metamorphic events in the Limpopo Belt: implications for the interpretation of P-T-t paths in metamorphic terrains: Geology, v. 22 , p. $1035-1038$.

Berger, M.; Kramers, J. D.; and Nägler, T. F., 1995, An Archean high-grade province adjacent to a granite greenstone terrain: geochemistry and geochronology of charnoenderbites in the Northern Marginal Zone of the Limpopo Belt, Southern Africa, and genetic models: Schweiz. Mineral. Petrogr. Mitt., v. 75, p. 17-42.

Berman, R. G., 1988, Internally consistent data for minerals in the system $\mathrm{Na}_{2} \mathrm{O}, \mathrm{K}_{2} \mathrm{O}, \mathrm{CaO}, \mathrm{MgO}, \mathrm{FeO}$, $\mathrm{Fe}_{2} \mathrm{O}_{3}, \mathrm{Al}_{2} \mathrm{O}_{3}, \mathrm{SiO}_{2}, \mathrm{TiO}_{2}, \mathrm{H}_{2} \mathrm{O}, \mathrm{CO}_{2}$ : Jour. Petrol., v. 29 , p. $445-522$.

- 1990, Mixing properties of Ca-Mg-Fe-Mn garnets.: Am. Mineral., v. 75, p. 328-344.

state and solution properties of olivine, orthopyroxene, garnet, cordierite, and biotite.: Geol. Soc. America Abs. with Prog., v. 25, p. A100.

von Blanckenburg, F., and Villa, I. M., 1988, Argon retentivity and argon excess in amphiboles from the garbenschists of the Western Tauern Window, Eastern Alps: Contrib. Mineral. Petrol., v. 100, p. 1-11.

Coward, M. P., and Fairhead, D. J., 1980, Gravity and structural evidence for the deep structure of the Limpopo Belt, South Africa: Tectonophysics, v. 68, p. 31-43.

—; James, P. R.; and Wright L., 1976, The northern margin of the Limpopo belt, southern Africa: Geol. Soc. America Bull., v. 87, p. 601-611.

Cox, K. G.; Johnson, R. L.; Monkman, L. J.; Stillman, C. J.; Vail, J. R.; and Wood, D. N., 1965, The geology of the Nuanetsi igneous province: Royal Soc. (London) Philos. Trans., v. 257, p. 71-218.

Dahl, P. S., 1994, Closing in on argon closure temperatures? An extended "ionic porosity" model for thermochronometric minerals, with application to amphiboles: U.S. Geol. Survey Circ. 1107, 72 p.

—, 1995, An "ionic porosity" approach to modeling compositional effects on diffusivity and retentivity of $\mathrm{Ar}$ and $\mathrm{O}$ in hornblende and related amphiboles: Geochim. Cosmochim. Acta, in press.

de Wit, M.; Roering, C.; Hart, J. R.; Armstrong, R. A.; de Ronde, C. E. J.; Green, R. W. E.; Tredoux, M.; Peberdy, E. P.; and Hart, R. A., 1992, Formation of an Archéan continent: Nature, v. 357, p. 553-562.

Dowty, E., 1980, Crystal-chemical factors affecting the mobility of ions in minerals: Am. Mineral., v. 65, p. 174-182.

Fitzsimons, I. C. W., and Harley, S. L., 1994, The influence of retrograde cation exchange on granulite P-T estimates and a convergence technique for the recovery of peak metamorphic conditions: Jour. Petrol., v. 35 , p. $543-576$.

Fortier, S. M., and Giletti, B. J., 1989, An empirical model for predicting diffusion coefficients in silicate minerals: Science, v. 245, p. 1481-1484.
Frei, R., and Kamber, B. S., 1995, Single mineral Pb-Pb dating: Earth Planet Sci. Lett., v. 129, p. 261-268.

Fuhrman, M. L., and Lindsley, D. H., 1988, Ternaryfeldspar modeling and thermometry: Am. Mineral., v. 73, p. 201-215.

Hamilton, J., 1977, Sr isotope and trace element studies of the Great Dyke and Bushveld Mafic Phase and their relation to early Proterozoic magma genesis in Southern Africa: Jour. Petrol., v. 18, p. 24-52.

Harley, S. L., 1989, The origins of granulites: a metamorphic perspective: Geol. Mag., v. 126, p. 215-247.

Hawthorne, F. C., 1983, The crystal chemistry of the amphiboles: Can. Mineral., v. 21, p. 171-180.

James, P. R., 1975, A deformation study across the northern margin of the Limpopo belt, Rhodesia: Unpub. Ph.D. dissertation, Leeds, UK.

Kamber, B. S.; Kramers, J. D.; Napier, R.; Cliff, R. A.; and Rollinson, H. R., 1995, The Triangle Shearzone, Zimbabwe, revisited: new data document an important event at $2.0 \mathrm{Ga}$ in the Limpopo Belt: Precamb. Res., v. 70, p. 191-213.

Kramers, J. D., 1988, An open-system fractional crystallization model for very early continental crust formation: Precamb. Res., v. 38, p. 281-295.

Kretz, R., 1983, Symbols for rock-forming minerals: Am. Mineral., v. 68, p. 277-279.

Lee, J. K. W., 1993, The argon release mechanisms of hornblende in vacuo: Chem. Geol., v. 106, p. $133-170$.

Lieberman, J., and Petrakakis, K., 1991, TWEEQU thermobarometry: analysis of uncertainties and applications to granulites from Western Alaska and Austria: Can. Mineral., v. 29, p. 857-887.

Mäder, U. K.; Percival, J. A.; and Berman, R. G., 1994, Thermobarometry of garnet-clinopyroxene-hornblende granulites from the Kapuskasing structural zone: Can. Jour. Earth. Sci., v. 31, p. 1134-1145.

McCourt, S., and Vearncombe, J. R., 1987, Shear zones bounding the central zone of the Limpopo Mobile Belt, southern Africa: Jour. Structural Geol., v. 9, p. 127-137.

- and -1992 , Shear zones of the Limpopo Belt and adjacent granitoid-greenstone terranes: implications for the late Archean collision tectonics on southern Africa: Precamb. Res., v. 55, p. 553-570.

McMullin, D. W.; Berman, R. G.; and Greenwood, H. J., 1991, Calibration of the SGAM thermobarometer for pelitic rocks using data from phase-equilibrium experiments and natural assemblages: Can. Mineral., v. 29, p. 889-908.

Mkweli, S.; Kamber, B. S.; and Berger, M., 1995, A westward continuation of the Zimbabwe CratonNorthern Marginal Zone tectonic break and new age constraints on the timing of thrusting: Jour. Geol. Soc. London, v. 152, p. 77-83.

Morgan, G. E., 1985, The paleomagnetism and cooling history of metamorphic and igneous rocks from the Limpopo Mobile Belt, southern Africa: Geol. Soc. America Bull., v. 96, p. 663-675.

Ridley, J. R., and Kramers, J. D., 1990, The evolution 
and tectonic consequences of a tonalitic magma layer within Archean continents: Can. Jour. Earth Sci., v. 27, p. 219-228.

, 1992, On the origins and tectonic significance of the charnockite suite of the Archean Limpopo Belt, Northern Marginal Zone, Zimbabwe: Precamb. Res., v. 55, p. 407-427.

Robertson, I. D. M., 1973, Potash granites of the southern edge of the Rhodesian craton and the northern granulite zone of the Limpopo Mobile Belt, in Lister, L. A., ed., Symposium on granites, gneisses, and related rocks: Geol. Soc. of South Africa Spec. Pub. 3, p. 265-276.

Roering, C.; van Reenen, D. D.; Smit, C. A.; Barton, J. M.; De Beer, J. H.; De Wit, M. J.; Stettler, E. H.; van Schalkwyk, J. F.; Stevens, G.; and Pretorious, S., 1992, Tectonic model for the evolution of the Limpopo Belt: Precamb. Res., v. 55, p. 539-552.

Rollinson, H. R., 1993, A terrane interpretation of the Archean Limpopo Belt: Geol. Mag., v. 130, p. 755-765.

, and Blenkinsop, T., 1995, The magmatic, metamorphic, and tectonic evolution of the Northern Marginal Zone of the Limpopo Belt in Zimbabwe: Jour. Geol. Soc. London, v. 152, p. 65-75.
Sanderson, D. J., and Marchini, W. R. D., 1984, Transpression: Jour. Structural Geol.: v. 6, p. 449-458.

Treloar, P. J.; Coward, M. P.; and Harris, N. B., 1992, Himalayan-Tibetan analogies for the evolution of the Zimbabwe Craton and Limpopo Belt: Precamb. Res., v. 55 , p. $571-587$.

van Breemen, O., and Dodson, M. H., 1972, Metamorphic chronology of the Limpopo Belt, Southern Africa: Geol. Soc. America Bull., v. 83, p. 2005-2018.

-, and Hawkesworth, C. J., 1980, Sm-Nd isotopic study of garnets and their metamorphic host rocks: Trans. Royal Soc. Edinburgh (Earth Sciences), v. 71, p. 97-102.

Watkeys, M. K., 1984, The Precambrian geology of the Limpopo Belt north and west of Messina: Unpub. Ph.D. dissertation, University of Witwatersrand, Johannesburg, South Africa.

Windley, B. F.; Ackermand, D.; and Herd, R. K., 1984, Sapphirine/kornerupine-bearing rocks and crustal uplift history of the Limpopo belt, Southern Africa: Contrib. Mineral. Petrol., v. 86 , p. 342-358.

- 1993, Uniformitarianism today: plate tectonics is the key to the past: Jour. Geol. Soc. London, v. 150, p. 7-19. 